\title{
Survei Potensi Sumber Daya Mineral di Kecamatan Silo Kabupaten Jember dengan menggunakan Metode Potensial Diri
}

\author{
Supeno \\ Program Studi Pendidikan Fisika, FKIP, Universitas Jember \\ Jl. Kalimantan 37, Jember \\ Agung T. Nugroho \\ Jurusan Fisika, FMIPA, Universitas Jember \\ Jl. Kalimantan 37, Jember \\ Widya Utama* \\ Laboratorium Geofisika, Jurusan Fisika, FMIPA \\ Institut Teknologi Sepuluh Nopember \\ Kampus ITS Sukolilo, Surabaya 60111
}

Intisari

\begin{abstract}
Hasil dari beberapa penelitian sebelumnya menunjukkan bahwa di daerah Silo Kabupaten Jember terdapat struktur mineral batuan khusus namun sebarannya belum diketahui. Untuk mengetahui potensi sumberdaya mineral tersebut terutama terkait dengan sebaran dan batas sebaran mineral, perlu dilakukan serangkaian pengukuran menggunakan metode potensial diri. Hasil penelitian menunjukkan bahwa sebaran mineral terletak di sekitar lintasan pengukuran 6,7, dan 8 serta berada dalam arah tegak lurus memotong arah lintasan memanjang mulai dari lintasan 1 hingga lintasan 9.
\end{abstract}

KATA KUNCI: potensial diri, mineral, Silo Jember

\section{PENDAHULUAN}

Penyebaran sumber daya energi berupa mineral ekonomis di Indonesia tidaklah merata. Seperti halnya penyebaran batuan, penyebaran mineral ekonomis sangat dipengaruhi oleh tatanan geologi Indonesia yang rumit. Mineral ekonomis adalah mineral bahan galian dan energi yang mempunyai nilai ekonomis. Mineral logam yang termasuk golongan ini adalah tembaga, besi, emas, perak, timah, nikel dan aluminium. Mineral non logam yang termasuk golongan ini adalah fosfat, mika, belerang, fluorit, mangan. Mineral industri adalah mineral bahan baku dan bahan penolong dalam industri, misalnya feldspar, ziolit, diatomea. Mineral energi adalah minyak, gas dan batubara atau bituminus lainnya. Belakangan panas bumi dan uranium juga masuk dalam golongan ini walaupun cara pembentukannya berbeda [1].

Carlile dan Mitchell (1994), Simanjuntak (1986), Sikumbang (1990), Cameron (1980), Adimangga dan Trail (1980) dalam Paripurno (2004) [2] memaparkan bahwa busur-busur magmatik seluruh Indonesia dapat dijadikan sebagai dasar eksplorasi sumber daya alam mineral. Teridentifikasikan sebanyak 15 busur magmatik, 7 diantaranya membawa jebakan emas dan tembaga, dan 8 lainnya belum diketahui. Busur

*E-MAIL: widya@physics.its.ac.id yang menghasilkan jebakan sumber daya mineral logam tersebut adalah busur magmatik Aceh, Sumatera-Meratus, SundaBanda, Kalimantan Tengah, Sulawesi-Mindanau Timur, Halmahera Tengah, Irian Jaya. Busur yang belum diketahui potensi sumber daya mineralnya adalah Paparan Sunda, Borneo Barat-laut, Talaud, Sumba-Timor, Moon-Utawa dan dataran Utara Irian Jaya. Jebakan tersebut merupakan hasil mineralisasi utama yang umumnya berupa porphyry coppergold mineralization, skarn mineralization, high sulphidation epithermal mineralization, gold-silver-barite-base metal mineralization, low sulphidation epithermal mineralizetion dan sediment hosted mineralization, Daerah penelitian ini adalah daerah Silo kabupaten Jember yang termasuk dalam busur magmatik Sunda-Banda.

Daerah Silo merupakan daerah perkebunan komersial terutama kopi dan jati dengan profil daerah berbukit-bukit. Secara umum batuan asal di daerah ini adalah batuan paparan Raung, merupakan anggota formasi Merawan dengan komposisi andesitik yang mengalami kloritisasi dan piritisasi. Perlapisan daerah tersebut memiliki barisan kemiringan lapisan terhadap horizontal yang merupakan aliran andesite aphyric basaltic dan aliran breksi, aliran andesite porphyritic dan aliran breksi, tuff dan breksi tuff, limestone dan breksi volkanik, tuff dan batuan pasir dan juga terdapat phorpyry quartz minor intrusive. Batuan ini digambarkan secara detail dalam laporan petrography oleh Townend [3] dan Purvis [4].

Hasil penelitian sebelumnya menggunakan pengukuran 
aero-magnetik yang dilakukan oleh Hakman Metalindo pada tahun 1999 menunjukkan bahwa di daerah ini terdapat anomali medan magnet bumi. Medan magnet bumi permukaan di daerah ini berkisar antara $44200 \mathrm{nT}$ sampai 46400 nT dan terdapat anomali magnetik klosur tertutup dengan nilai $45400 \mathrm{nT}$ - $46400 \mathrm{nT}$. Tafsiran geologis lokal sementara terhadap sumber anomali geomagnet regional di daerah ini berupa keberadaan struktur batuan khusus. Hasil ini diperkuat dengan adanya penelitian awal geologi permukaan dan data hasil uji laboratorium terhadap contoh batuan pada beberapa daerah singkapan yang menunjukkan bahwa terdapat potensi kandungan beberapa mineral logam berharga yaitu $\mathrm{Au}, \mathrm{Pb}, \mathrm{Cu}$ dan Ag.

Berdasarkan hasil penelitian sebelumnya, dengan asumsi bahwa daerah penelitian merupakan daerah dangkal yang mempunyai struktur dan kemiringan, kompleks yang mengalami alterasi sehingga perbedaan struktur ini akan membangkitkan beda potensial listrik antara batuan yang berada di atas muka air tanah dengan batuan atau mineral di bawahnya serta membangkitkan potensial listrik yang berbeda antara daerah kandungan dengan daerah sekitarnya sehingga dengan metode potensial diri, sebaran dan batas sebaran dari batuan khusus ini dapat diungkap. Berdasarkan hal ini, untuk lebih meyakinkan terhadap keberadaan anomali mineral ekonomis, perlu dilakukan pengukuran parameter fisis kelistrikan berupa potensial alamiah dengan menerapkan metode potensial diri.

Prinsip dasar metode potensial diri adalah pengukuran potensial alamiah yang dilakukan pada sejumlah titik tertentu di permukaan tanah. Parameter yang diukur dalam metode ini adalah beda potensial relatif dengan anggapan bahwa di titik jauh tak terhingga sama dengan nol [5]. Potensial listrik di permukaan tanah diukur dengan menggunakan voltmeter dan kontak antara voltmeter dengan tanah menggunakan suatu elektroda non polar (non-polarizing electrodes). Hasil akhir dari survei potensial diri adalah data berupa nilai potensial terukur dengan jarak spasi tertentu yang kemudian dibuat grafik antara offset dengan nilai potensial terukur dan peta kontur ekuipotensial. Interpretasi data dilakukan dengan cara melihat data hasil pengukuran yang bervasiasi dari beberapa milivolt sampai ratusan milivolt dan vasriasi polaritas positif atau negatif yang tergantung kondisi geologi atau sumber jebakan yang menyebabkannya [6].

Mekanisme potensial diri dalam zona mineral tidak sepenuhnya dapat dipahami walaupun beberapa teori telah dikembangkan untuk menjelaskannya. Pengukuran lapangan menunjukkan bahwa beberapa bagian mineral harus berada dalam zona oksidasi dimana anomali potensial diri dapat muncul di permukaan. Penjelasan awal berdasarkan pada beberapa kejadian bahwa mineral berlaku seperti sel galvanik dimana perbedaan potensial dihasilkan diantara zona teroksidasi yang umumnya berada di bagian atas permukaan.

Teori potensial mineralisasi dijelaskan oleh Sato dan Mooney pada tahun 1960 dan membuat postulat sel reaksi elektrokimia, yaitu reaksi sel yang berlawanan tanda, katodik berada di atas water table dan anodik berada di kedalaman. Pada sel katodik terdapat reduksi kimiawi dari substansi dalam larutan (peningkatan elektron) sementara pada anodik terjadi reaksi oksidasi dan kehilangan elektron. Zona min- eral itu sendiri berfungsi hanya untuk transport elektron dari anoda ke katoda. Besarnya seluruh efek potensial diri ditentukan oleh perbedaan potensial oksidasi antara larutan pada kedua sel tersebut.

\section{METODE PENELITIAN}

Pengukuran parameter kelistrikan berupa potensial diri dilakukan pada beberapa lintasan yang saling sejajar pada daerah penelitian. Sebagai langkah awal dari penelitian ini adalah survey awal untuk menentukan posisi dan jaringan titik ukur. Untuk mendukung kegiatan ini diperlukan seperangkat peralatan berupa Global Positioning System (GPS), kompas, handy talky, pita meter, palu geologi, tools kit, dan beberapa peralatan pendukung. Selanjutnya dilakukan pengukuran topografi untuk menentukan relief permukaan keseluruhan daerah penelitian. Pengukuran topografi dilakukan dengan menggunakan peralatan theodolit, GPS, dan beberapa peralatan pendukung.

Kegiatan selanjutnya adalah pengukuran potensial diri untuk menentukan sebaran dan batas-batas sebaran kandungan mineral. Peralatan yang dipelukan dalam pengukuran potensial diri adalah multimeter digital berimpedansi rendah, elektrode porous pot, kabel, meteran, alat pencatat waktu, handy talky, palu geologi, tools kit, dan beberapa peralatan pendukung. Pengukuran dilakukan pada beberapa lintasan dan mencakup seluruh daerah penelitian dengan mengambil jarak antar lintasan sejauh $160 \mathrm{~m}$ dan jarak antar elektrode porous pot adalah sebesar $25 \mathrm{~m}$. Berdasarkan pertimbangan keadaan lokasi penelitian, untuk lintasan 9 hingga 11 memiliki jarak antar lintasan sebesar $80 \mathrm{~m}$. Profil lintasan yang digunakan selama akusisi data ditunjukkan pada Gambar 1, sedangkan skema konfigurasi elektrode selama pengukuran potensial diri ditunjukkan pada Gambar 2.

Parameter kelistrikan yang diperoleh dari pengukuran potensial diri adalah nilai beda potensial listrik pada setiap titik pengukuran dan mencakup seluruh daerah penelitian. Data beda potensial listrik hasil pengukuran potensial diri, selanjutnya dengan bantuan komputer dapat dibuat grafik hubungan antara potensial diri terukur dengan offset. Selain itu juga dapat dibuat kontur beda potensial 2 dimensi (2D) maupun 3 dimensi (3D) yang digunakan untuk menggambarkan sebaran mineral di permukaan pada arah horizontal lateral.

\section{HASIL DAN PEMBAHASAN}

Pengukuran data potensial diri dilakukan pada 11 lintasan dengan spasi adalah sebesar $25 \mathrm{~m}$, panjang lintasan $500 \mathrm{~m}$ dan jarak antar lintasan sebesar tidak tergantung pada kondisi medan di lapangan. Jarak antar lintasan untuk lintasan 1 hingga lintasan 8 adalah sebesar $160 \mathrm{~m}$ sedangkan untuk lintasan 8 hingga lintasan 11 berjarak $80 \mathrm{~m}$. Daerah cakupan pengukuran adalah seluas $1520 \mathrm{~m} \times 500 \mathrm{~m}$. Pada jarak 100 meter pertama lintasan 1 merupakan lahan kopi, sedangkan sisanya adalah lahan persawahan kering yang ditanami padi 


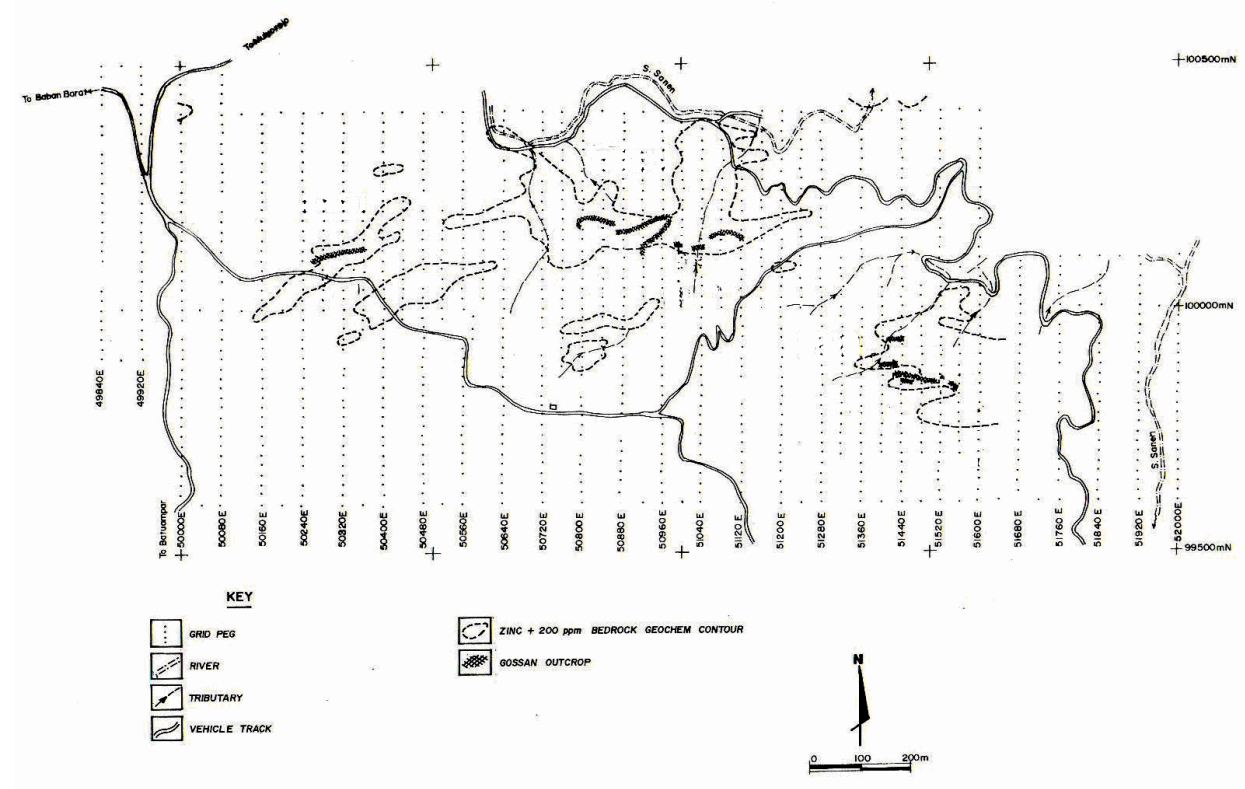

Gambar 1: Profil lintasan dalam pengukuran potensial diri
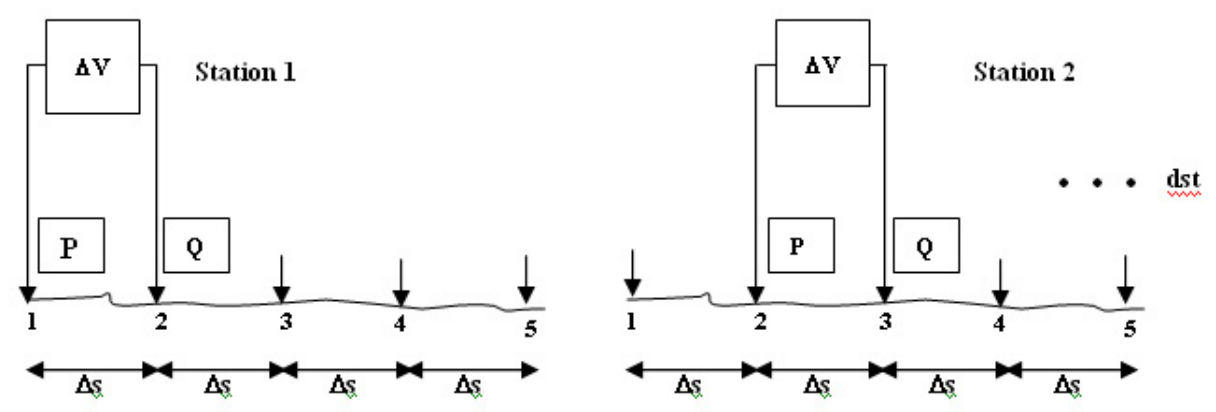

Gambar 2: Konfigurasi elektrode dalam pengukuran potensial diri

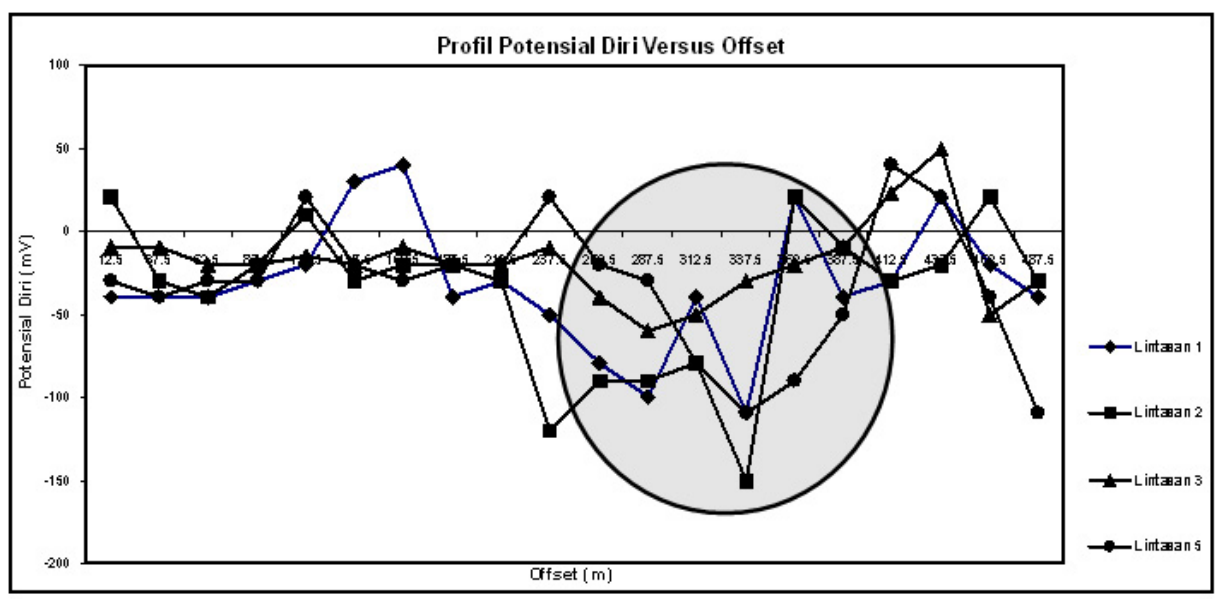

Gambar 3: Posisi anomali potensial diri pada lintasan 1 hingga lintasan 5

090101-3 


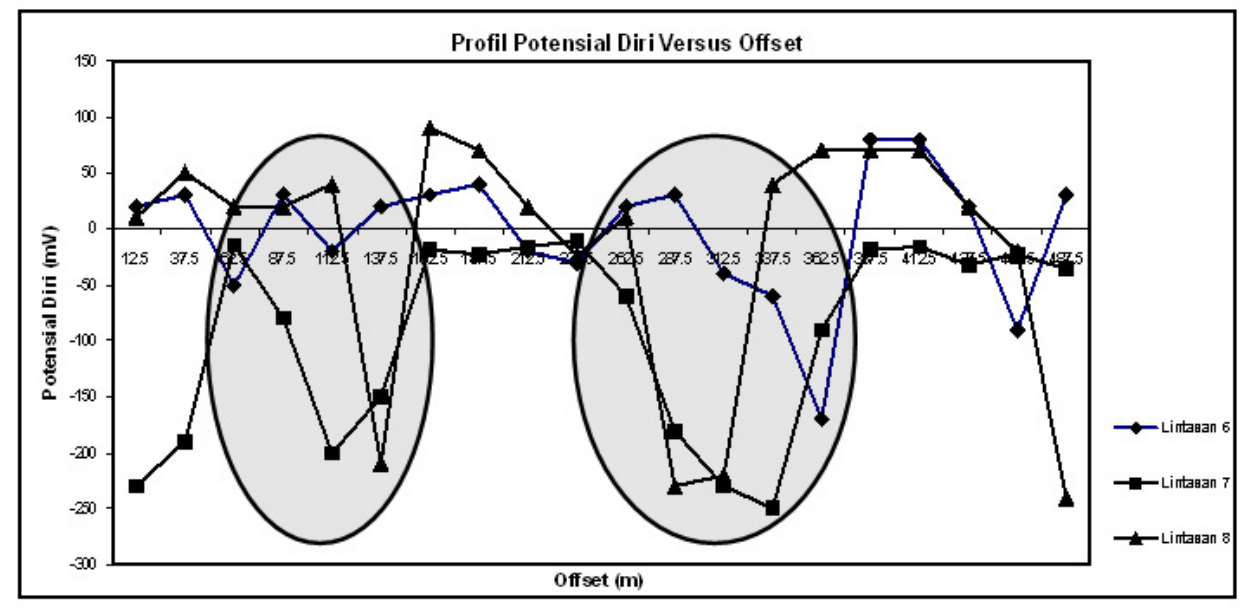

Gambar 4: Posisi anomali potensial diri pada lintasan 6 hingga lintasan 8

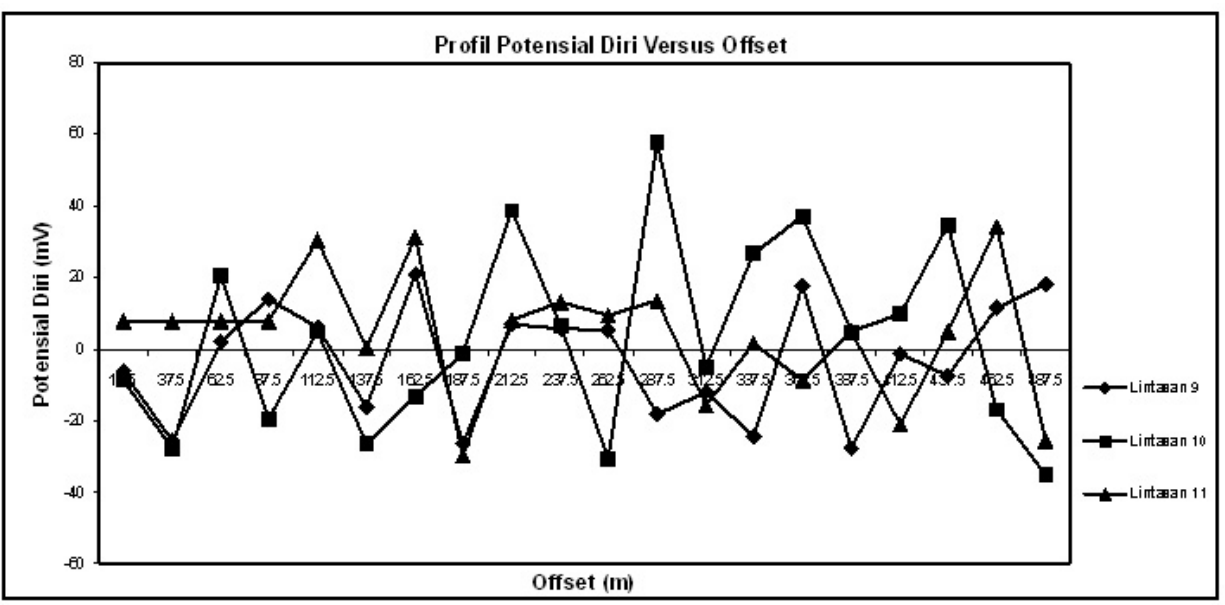

Gambar 5: Potensial diri lintasan 9 hingga lintasan 11 yang tidak menunjukkan adanya anomali

dan kacang tanah dan kedelai. Pada lintasan 1 terdapat beberapa singkapan yang memperlihatkan batuan yang berwarna merah. Lintasan 2 merupakan lahan kopi, dan singkapan batuan berwarna hijau. Pada jarak 200 meter terakhir lintasan 3 merupakan kawasan penduduk dan selebihnya merupakan lahan perkebunan kopi. Pada lintasan 3 tidak ada singkapan yang ditunjukkan pada daerah ini. Lintasan 4, 5, 6 melalui kebun kopi dan jati. Pada lintasan 4 terdapat singkapan batuan yang berwarna hijau pada jarak 75 meter dari titik awal pengukuran. Lintasan 7 hingga lintasan 11 merupakan lahan kebun kopi dan sengon.

Anomali potensial diri yang berasosiasi dengan keberadaan mineral adalah potensial diri yang berharga rendah. Pada lintasan 1 hingga lintasan 5, anomali potensial diri berada pada offset antara titik $265 \mathrm{~m}$ hingga 387,5 m sebagaimana ditunjukkan pada Gambar 3. Sedangkan pada lintasan 6 hingga lintasan 8 , anomali potensial diri berada dua daerah yaitu pada offset antara titik $62,5 \mathrm{~m}$ hingga $137,5 \mathrm{~m}$ dan pada offset antara titik 262,5 m hingga 362,5 m sebagaimana ditunjukkan pada Gambar 4. Pada lintasan 9, 10 dan 11, harga potensial diri cenderung sama dan tidak menunjukkan adanya anomali yang ditunjukkan pada Gambar 5.

Berdasarkan data potensial diri hasil pengukuran pada seluruh lintasan, dapat dibuat kontur potensial baik dalam bentuk 2 (2D) maupun 3 dimensi (3D) dengan sebagaimana yang ditunjukkan pada Gambar 6 dan Gambar 7. Pada Gambar 6 nampak bahwa di daerah penelitian terdapat pola-pola anomali di lintasan 6,7, dan 8. Selain itu juga nampak adanya pola anomali dalam arah tegak lurus memotong arah lintasan mulai dari lintasan 1 hingga lintasan 9.

Adanya anomali potensial baik di sekitar lintasan 6, 7, dan 8 maupun anomali potensial dalam arah tegak lurus memotong lintasan nampak lebih terlihat pada kontur 3D (Gambar 7). Anomali potensial yang terdapat di sekitar lintasan 6,7 , dan 8 serta anomali dalam arah tegak lurus memotong arah lintasan mulai dari lintasan 1 hingga lintasan 9 tersebut diindikasikan sebagai posisi dari keberadaan struktur batuan khusus yang mengarah pada mineral logam. Hal ini didasarkan pada penelitian sebelumnya yaitu hasil uji laboratorium terhadap batuan pada beberapa daerah singkapan yang 


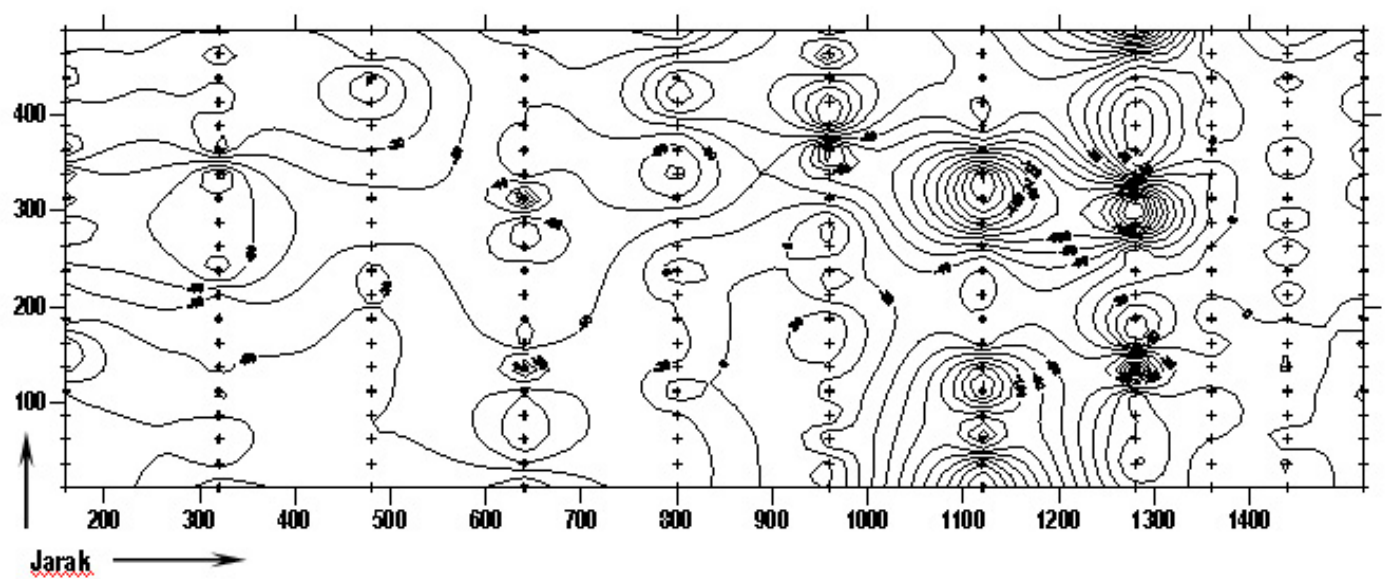

Gambar 6: Kontur potensial diri daerah penelitian dalam bentuk 2D

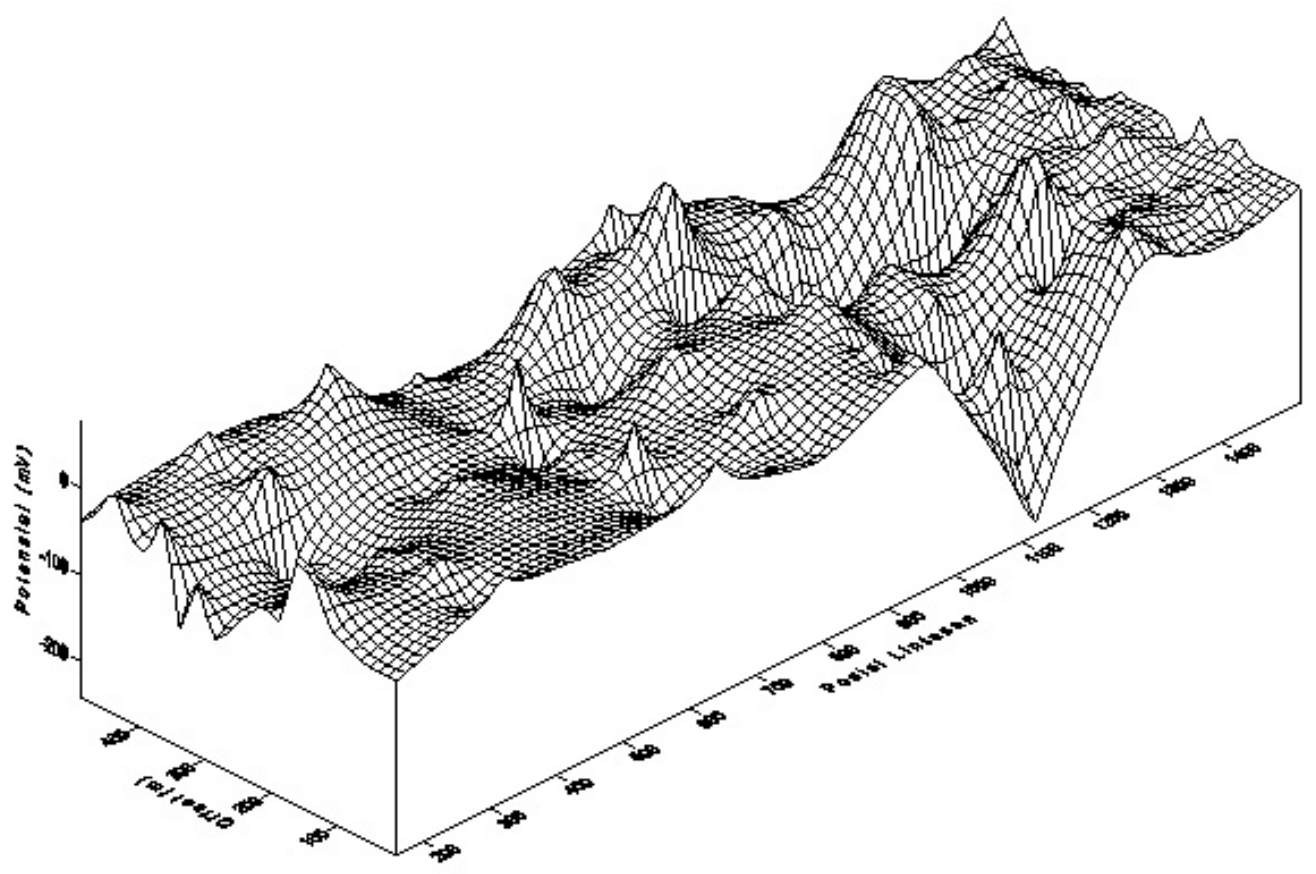

Gambar 7: Kontur potensial diri daerah penelitian dalam bentuk 3D

mencirikan bahwa batuan yang teridentifikasi adalah mengandung logam.

\section{SIMPULAN DAN SARAN}

Hasil interpretasi terhadap hasil pengukuran parameter fisis lapisan tanah daerah penelitian dengan menerapkan metode potensial diri menunjukkan bahwa di daerah Silo kabupaten Jember terdapat anomali-anomali potensial diri yang dapat diinterpretasikan sebagai fenomena yang berasosiasi dengan keberadaan sebaran mineral. Hasil interpretasi pengukuran potensal diri hanya menggambarkan keberadaan mineral di permukaan atau dekat permukaan pada sebaran lateral dan belum dapat digunakan untuk menentukan berapa kedalaman dan bentuk atau model mineral yang terdapat di daerah penelitian. Agar dapat diperoleh gambaran yang lebih detil tentang keberadaan mineral di daerah penelitian terutama terkait dengan kedalaman dan bentuk atau model mineral yang ada maka perlu dilakukan pengukuran lanjutan dengan menggunakan metode geolistrik resistivitas.

Walaupun hasil pengukuran menggunakan metode potensial diri masih terbatas pada interpretasi di permukaan namun hasil tersebut dapat dipergunakan bagi pihak terkait baik itu pemerintah daerah, para investor atau bahkan masyarakat setempat sebagai informasi awal untuk kegiatan pengelolaan sumber daya alam yang terkandung di daerah penelitian. 


\section{Ucapan Terima Kasih}

Kami ucapkan terimakasih yang sebesar-besarnya kepada: Direktorat Penelitian dan Pengabdian Pada Masyarakat (DP2M) Ditjen Pendidikan Tinggi yang memberikan dukungan biaya penelitian ini dalam kerangka Hibah Pekerti 2008 -
2009, LPPM Universitas Jember dan LPPM Institut Teknologi Sepuluh Nopember (ITS) dan Jurusan Fisika FMIPA ITS, Surabaya atas dukungan terhadap pelaksanaan penelitian ini. Kami sampaikan pula penghargaan yang tinggi kepada sejawat peneliti pada Lab. Geofisika ITS atas masukan dan diskusi yang sangat bernas dalam penelitian ini.
[1] Sudradjat. D., Geologi Ekonomi (Diktat Kuliah, Laboratorium Geologi Ekonomi, Jurusan Pendidikan Geologi, Fakultas Teknologi Industri, Institut Teknologi Bandung, 1982)

[2] Paripurno, Eko T., Hubungan Antara Kondisi Geodinamik Dengan Pembentukan Mineral Di Indonesia (http://publik.geopangea.or.id/ekoteguh/, diakses pada 1 Februari 2006)

[3] Townend, R., Petrographics Description, 24 Thin Section (Petrographics Description R. Townend and Associates, Report
E05/1994/6, 1997)

[4] Purvis, A C., Mineralogical Report No. 7409, (Pontifex and Associates Pty Ltd. Report E05/1997/6, 1997)

[5] Sheriff, R. E., Encyclopedic Dictionary of Applied Geophysics, $4^{\text {th }}$ (SEG, Tulsa Oklahoma, 2002)

[6] Telford, W. M, Geldart, L. P. and Sheriff, R. E., Applied Geophysics, Second Edition (United State of America, 1990) 